$\begin{array}{ll}\text { Research Square } & \text { Preprints are preliminary reports that have not undergone peer review. } \\ \text { They should not be considered conclusive, used to inform clinical practice, } \\ \text { or referenced by the media as validated information. }\end{array}$

\title{
Selenium and the risk of cardiovascular disease and all-cause mortality: a meta-analysis of prospective observational studies and randomized controlled trials
}






\section{Abstract}

\section{Background}

This meta-analysis of prospective observational studies and randomized controlled trials (RCTs) was carried out to explore the association between selenium and the risk of cardiovascular disease (CVD) and all-cause mortality.

\section{Methods and Study Design}

We searched the PubMed, EMBASE and Web of Science database for eligible studies which included the relationship between selenium and the outcomes of interest. 25 prospective observational studies and 9 RCTs were included in our meta-analysis.

\section{Results}

The observational studies showed that there was a significant inverse association between serum selenium and the risk of CVD (RR: 0.78; $95 \%$ Cl: $0.68-0.89$ ), coronary heart disease (CHD) (RR: $0.75 ; 95 \% \mathrm{Cl}: 0.58-0.95)$ and all-cause mortality (RR: $0.77 ; 95 \% \mathrm{Cl}: 0.71-0.84$ ). We also found a significant inverse association between selenium supplements and the risk of total CVD (RR: $0.78 ; 95 \%$ Cl: $0.62-0.98$ ) and all-cause mortality (RR: $0.81 ; 95 \%$ Cl: $0.65-1.00)$ in RCTs studies.

\section{Conclusions}

Our meta-analysis found a significant inverse association between selenium and CVD, CHD, and all-cause mortality in prospective observational studies and RCTs, which indicate the selenium has protective effect in cardiovascular disease and all-cause mortality.

\section{Introduction}

Selenium is an essential trace element which has received considerable attention for its antioxidant properties mediated by selenium-dependent glutathione peroxidases and other selenoproteins $(1,2)$. Food including grains, brazil nuts, seafood and meat is the main source of selenium(3). The predominant dietary forms Se are selenocysteine and selenomethionine(4). Since the selenium foods content is widely various as the foods are grown in the different selenium concentration of soil and water, it is not accurate to estimate the average dietary selenium intake by using available food composition data(5-7). A previous study demonstrated that the average recommended daily intake of selenium for adults is $53 \mu \mathrm{g} / \mathrm{day}$ for women and $60 \mu \mathrm{g} / \mathrm{day}$ for men(8).

Despite the availability of many selenium-rich foods, such as sea food, dairy, animal liver, meat, nuts, selenium deficiency occurred in regions of China, Russia and a lesser extent parts of Europe(9). Several previous studies have found that selenium deficiency was association with the risk of cardiovascular disease (CVD)(10). In a previous case-control study, serum selenium concentrations were lower in CVD patients than in healthy populations(11). A previous metaanalysis study in the 2006 including 14 prospective observational studies found a significant inverse correlation between selenium and coronary heart disease (RR: $0.85 ; 95 \% \mathrm{Cl}$ : 0.74-0.99)(12), while it was inconsistent with another meta-analysis which included 9 randomized controlled trials (RCTs) studies, and the result indicated that there was no significant benefits from selenium supplement for CVD (RR: 0.91; 95\% Cl: 0.74-1.10)(13). Despite these promising data(13, 14), studies of the impact of selenium deficiency on CVD have produced inconsistent conclusion.

In recent years, there were a great number of prospective observations and RCTs studies focused on the correlation between selenium and the risk of cardiovascular disease and all-cause mortality, provided results may contribute to a pooled result. Therefore, in this paper we undertook a comprehensive meta-analysis to explore the relationship between selenium and the risk of CVD and all-cause mortality.

\section{Materials And Methods}

This meta-analysis followed the Meta-analysis of Observation Studies in Epidemiology(MOOSE)(15) guidelines and the PRISMA statement(16, 17).

\section{Search strategy}

We searched the PubMed, Embase and Web of Science databases for all relevant articles published up to April 8, 2018. The following keywords were used: "selenium" AND ("cardiovascular disease" OR “CVD" OR "heart disease" OR "heart failure" OR "heart attack" OR "myocardial infarction" OR "stroke" OR "coronary heart disease" OR "ischemic heart disease" OR "coronary arteriosclerosis" OR "coronary atherosclerosis" OR "mortality" OR "death") AND ("cohort" OR "prospective" OR "follow-up" OR “longitudinal" OR "case-control" OR "incident" OR “incidence" OR "randomized controlled trials" OR "population"). The search was restricted in human being studies, but no language restriction.

\section{Study selection}

Eligible articles met the following criteria: (1) original studies (no meeting abstracts or reviews); (2) adult population (age >18 years old) and no other disease; (3) prospective study design or RCTs; (4) must provide the relative risk (RR) or hazard ratios (HR) and 95\% confidence intervals (95\% Cl); (5) the exposure was serum or supplement selenium; (6) the outcomes was all-cause mortality or CVD (including cardiovascular disease, coronary heart disease(CHD), myocardial infarction(MI), stroke); (7) RCTs studies provided the dose of selenium supplement. To ensure the accuracy of the eligible studies, two investigators (author Hualei Sun and Shao Rong Long) independently screened the title and abstract of all studies, then evaluated the remaining studies according the including criteria. When encountered the duplicate studies, the one with the large sample size and the longest follow-up studies was selected.

3. Data extraction 
Two investigators (authors Hualei Sun and Shao Rong Long) extracted the data independently. Discrepancies were settled by discussion to reach a consensus. We asked for help by contacting the author when there was no relevant data in the original text. We extracted the following information: the first author's last name, publication year, study location, source of the study, sex and age of the participant, follow-up time, CVD outcomes, sample size, the range of selenium exposure, the method of selenium assessment, the dose of selenium supplement, and the risk estimates with $95 \% \mathrm{Cl}$. We chose the most adjustment risk estimates as our results.

The quality of observation study was assessed according the Newcastle-Ottawa Scale (NOS)(18). It evaluates the quality of the study from three aspects: selection, comparability, and outcome or exposure. We considered $0-3,4-6,7-9$ scores as low, moderate and high quality, respectively. The quality of RCTs were conducted by Jadad scale(19), the score ranges was from 0 to 5 , and we considered $0-2,3-5$ scores as low and high quality, respectively.

\section{Statistical analysis}

The observational studies and RCTs were analyzed separately. Relative risks and $95 \% \mathrm{Cl}$ were used to combine the result, at the same time, the ratio of odds, hazard rates and morbidity was considered as approximate $\mathrm{RR}(20,21)$. For the three studies that considered the serum selenium as a continuous variable, we derived the relative risk with an increase of one SD serum concentration(22-24). Studies that stratified the data of CHD, MI or stroke were treated as two separated studies. When studies did not provide the mean serum selenium concentration of per category, the categorical midpoint was used. When dealing with the open-ended category, we regarded the length of the category was same as other categories. When studies defined the highest category of selenium as the reference, we converted the original data into the lowest category as the reference, according the method proposed by Hamling(25).

We used an inverse-variance weighted random-effect model to pool the RRs and its $95 \% \mathrm{Cl}$ from the individual study. The between-study heterogeneity was estimated by 12 statistic, we defined the values of $25 \%, 50 \%$, and $75 \%$ as low, moderate and high heterogeneity, respectively(26). Subgroup and metaregression were performed to explore the possible confounding factors, including sex, sample size, trial duration, and selenium supplement. We also examined whether selenium supplements (selenium alone or combined with other minerals) or the dose of supplements $(200 \mu \mathrm{g} / \mathrm{d}$ or $\leq 100 \mu \mathrm{g} / \mathrm{d}) \mathrm{modified} \mathrm{the} \mathrm{result} \mathrm{of}$ RCTs studies.

We performed the sensitivity analysis to assess each study on pooled estimates by excluding one study at a time for the both observational studies and RCTs. Publication bias was assessed by funnel plots using Egger's and Begger's test(27, 28). All statistical analyses were conducted using Stata version 12 (STATA Corporation, College Station, TX, USA). The value of $\mathrm{P}<0.05$ was considered statistically significant.

\section{Results}

The detailed process of our literature search selection was shown in Fig. 1. We identified 3859 articles according the search strategy, including 614 articles from PubMed, 1572 articles from Embase, and 1673 articles from Web of science. After screening the duplicates and excluding the studies according the inclusion criteria, 25 prospective observational studies(22-24, 29-50) comprised of 44 reports and 9 RCTs studies(51-59) comprised of 18 reports were included in our meta-analysis.

\section{Study characteristic}

The 25 observational studies involved 3920 cases of CVD, 2394 cases of CHD, 1330 cases of MI, 320 cases of stroke, and 14,308 cases of deaths. The studies were published from 1982 to 2019 , and the duration of follow-up ranged from 3 to 16 years. The studies were from 11 different countries ( 7 studies from United States, 5 studies from Finland, 3 studies from Sweden, 2 studies from Norway, and one each in the Netherland, Denmark, China, France, Spain, Italy, and British). Thirteen studies recruited both males and females, ten studies recruited only males, and 2 studies recruited only females. The quality of scores of observational studies ranged from 6 to 9 , and the mean score was 7.6. The detail characteristics of the 25 prospective observational studies were shown in Table 1.

Table 1 Characteristics of the prospective observational studies 


\begin{tabular}{|c|c|c|c|c|c|c|c|c|c|}
\hline $\begin{array}{l}\text { First author, } \\
\text { year }\end{array}$ & Country & Source & Sex & $\begin{array}{l}\text { Age } \\
\text { (years) }\end{array}$ & $\begin{array}{l}\text { Follow- } \\
\text { up } \\
\text { (years) }\end{array}$ & 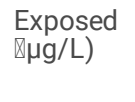 & $\begin{array}{l}\text { Reference } \\
(\mu \mathrm{g} / \mathrm{L})\end{array}$ & Outcomes & Assessment \\
\hline Salonen,1982 & Finland & $\begin{array}{l}\text { Eastern } \\
\text { Finland Heart } \\
\text { survey }\end{array}$ & $\mathrm{M} / \mathrm{F}$ & $35-59$ & 7 & $\geq 45$ & $<45$ & $\begin{array}{l}\text { CVD mortality }(283 / 283), \mathrm{CHD} \\
\text { mortality }(95 / 95) \llbracket \mathrm{MI} \\
\text { mortality }(252 / 252)\end{array}$ & AAS(serum) \\
\hline Miettinen,1983 & Finland & $\begin{array}{l}\text { Eastern } \\
\text { Finland Heart } \\
\text { survey }\end{array}$ & M & 48 & $5-7$ & $\geq 82.6$ & $<63.2$ & MI incidece (33/64) & AAS(serum) \\
\hline Salonen,1985 & Finland & $\begin{array}{l}\text { Eastern } \\
\text { Finland Heart } \\
\text { survey }\end{array}$ & $M / F$ & $30-64$ & 5 & $\geq 45$ & $<45$ & CHD mortality (92/92) & AAS(serum) \\
\hline Virtamo,1985 & Finland & $\begin{array}{l}\text { National } \\
\text { Death } \\
\text { Certificate } \\
\text { Register }\end{array}$ & M & $55-74$ & 5 & $\geq 45$ & $<45$ & $\begin{array}{l}\text { CVD mortality }(42 / 579), \text { CHD } \\
\text { mortality ( } 30 / 591) \text {, MI mortality } \\
(45 / 566) \text {,Total deaths }(74 / 547)\end{array}$ & AAS(serum) \\
\hline Ringstad,1986 & Norway & $\begin{array}{l}\text { The First The } \\
\text { Troms } \varnothing \\
\text { Heart Study }\end{array}$ & M & $20-49$ & 8 & $\geq 98.7$ & $<98.7$ & MI incidece (99/99) & AAS(serum) \\
\hline Kok,1987 & Netherlands & $\begin{array}{l}\text { Epidemiologic } \\
\text { Prevention } \\
\text { Study } \\
\text { Zoetermeer }\end{array}$ & $\mathrm{M} / \mathrm{F}$ & $37-87$ & 9 & $\geq 105.4$ & $<105.4$ & $\begin{array}{l}\text { CVD mortality (84/168),CHD } \\
\text { mortality } \\
(56 / 168), \text { stroke(15/168) }\end{array}$ & NAA(serum) \\
\hline Ringstad,1987 & Norway & $\begin{array}{l}\text { The Second } \\
\text { The Troms } \varnothing \\
\text { Heart Study }\end{array}$ & M & $28-54$ & 6 & $\geq 114.5$ & $<114.5$ & MI incidece (59/59) & AAS(serum) \\
\hline Suadicani,1992 & Denmark & $\begin{array}{l}\text { The } \\
\text { Copenhagen } \\
\text { Male Study }\end{array}$ & M & $53-74$ & 3 & $>78.96$ & $\leq 78.96$ & CHD incidence $(107 / 2715)$ & AAS(serum) \\
\hline Salvini,1995 & USA & $\begin{array}{l}\text { The } \\
\text { Physicians' } \\
\text { Health Study }\end{array}$ & M & $40-84$ & 5 & $>133.5$ & $<92.5$ & MI incidece (186/186) & NAA(serum) \\
\hline Marniemi,1998 & Finland & $\begin{array}{l}\text { Health survey } \\
\text { with complete } \\
\text { clinical } \\
\text { evaluation }\end{array}$ & $\mathrm{M} / \mathrm{F}$ & $\geq 65$ & 13 & $>89.6$ & $<68.2$ & CVD mortality $(142 / 202)$ & AAS(serum) \\
\hline Kilander,2001 & Sweden & $\begin{array}{l}\text { The Uppsala } \\
\text { health survery }\end{array}$ & $M$ & $49-51$ & 25 & $1 \mathrm{sd}$ & $1 \mathrm{sd}$ & $\begin{array}{l}\text { CVD mortality (301/1727), Total } \\
\text { deaths }(630 / 1398)\end{array}$ & AAS(serum) \\
\hline Yoshizawa,2003 & USA & $\begin{array}{l}\text { The Health } \\
\text { Professionals } \\
\text { Follow-up } \\
\text { Study }\end{array}$ & M & $40-75$ & 5 & $\geq 105.4$ & $<105.4$ & $\begin{array}{l}\text { CHD incidence (470/465),Ml } \\
\text { incidence }(225 / 465)\end{array}$ & NAA(toenails \\
\hline Wei,2004 & China & $\begin{array}{l}\text { The Nutrition } \\
\text { Intervention } \\
\text { Trial in } \\
\text { Linxian }\end{array}$ & $\mathrm{M} / \mathrm{F}$ & $40-69$ & 15 & $>94$ & $\leq 60.8$ & $\begin{array}{l}\text { CHD mortality } \\
\text { (116/987),stroke(167/936), Total } \\
\text { deaths }(516 / 587)\end{array}$ & AAS(serum) \\
\hline
\end{tabular}

Table 1 Characteristics of the prospective observational studies 


\begin{tabular}{|c|c|c|c|c|c|c|c|c|c|c|}
\hline Akbaraly,2005 & France & $\begin{array}{l}\text { Etide du } \\
\text { Vieillissement } \\
\text { Arteriel }\end{array}$ & $M / F$ & $\begin{array}{l}59- \\
71\end{array}$ & 9 & $\geq 96.3$ & $<75.8$ & $\begin{array}{l}\text { CVD mortality (22/1367), Total } \\
\text { deaths }(101 / 1288)\end{array}$ & AAS(serum) & 8 \\
\hline Ray,2006 & US & $\begin{array}{l}\text { The Women's } \\
\text { Health and } \\
\text { Agingstduies } \\
\text { I and II in } \\
\text { Baltimore, } \\
\text { MD }\end{array}$ & $\mathrm{F}$ & $\begin{array}{l}70- \\
79\end{array}$ & 5 & $1 s d$ & $1 s d$ & Total deaths $(89 / 543)$ & AAS(serum) & 6 \\
\hline Walston,2006 & US & $\begin{array}{l}\text { The Women's } \\
\text { Health and } \\
\text { Aging stduies } \\
\text { I in } \\
\text { Baltimore, } \\
\text { MD }\end{array}$ & $\mathrm{F}$ & $\geq 65$ & 5 & $>122.8$ & $\leq 109.9$ & Total deaths $(197 / 422)$ & AAS(serum) & 8 \\
\hline Gonzalez,2007 & Spain & $\begin{array}{l}\text { Recruited in } \\
\text { fourteen } \\
\text { elderly care } \\
\text { institutions } \\
\text { from Asturius }\end{array}$ & $M / F$ & $\geq 60$ & 4.3 & $>99.5$ & $\leq 72.6$ & Total deaths $(60 / 155)$ & AAS(serum) & 7 \\
\hline Bleys,2008 & USA & $\begin{array}{l}\text { The Third } \\
\text { National } \\
\text { Health and } \\
\text { Nutrition } \\
\text { Examination } \\
\text { Survey }\end{array}$ & $M / F$ & $\begin{array}{l}20- \\
90\end{array}$ & 12 & $\geq 130.39$ & $<117.31$ & $\begin{array}{l}\text { CVD mortality (881/13006),CHD } \\
\text { mortality } \\
(390 / 13497), \text { stroke(138/13749)Total } \\
\text { deaths (1968/11919) }\end{array}$ & AAS(serum) & 9 \\
\hline Lauretani,2008 & Italy & $\begin{array}{l}\text { "Aging in the } \\
\text { chianti Area" } \\
\text { study }\end{array}$ & $M / F$ & $\geq 65$ & 6 & $>81.9$ & $<66.2$ & Total deaths $(237 / 805)$ & AAS(plasma) & 8 \\
\hline Eaton,2010 & USA & $\begin{array}{l}\text { The Third } \\
\text { National } \\
\text { Health and } \\
\text { Nutrition } \\
\text { Examination } \\
\text { Survey }\end{array}$ & $M / F$ & $\geq 35$ & 13.4 & $>98$ & $\leq 98$ & $\begin{array}{l}\text { CHD mortality }(1038 / 9493), \text { Total } \\
\text { deaths }(3944 / 6587)\end{array}$ & AAS(serum) & 8 \\
\hline Bates,2011 & British & $\begin{array}{l}\text { The British } \\
\text { National Diet } \\
\text { and Nutrition } \\
\text { Survery }\end{array}$ & $M / F$ & $\geq 65$ & 13 & $1 \mathrm{sd}$ & $1 \mathrm{sd}$ & $\begin{array}{l}\text { CVD mortality (189/865), Total } \\
\text { deaths }(717 / 337)\end{array}$ & $\begin{array}{l}\text { ICP-MS } \\
\text { 『plasma) }\end{array}$ & 7 \\
\hline Wennberg,2011 & Sweden & $\begin{array}{l}\text { The Northern } \\
\text { Sweden } \\
\text { Health and } \\
\text { Disease } \\
\text { Study }\end{array}$ & M & $\begin{array}{l}30- \\
77\end{array}$ & 13 & $>134.5$ & $<117$ & MI incidece (431/499) & $\begin{array}{l}\text { ICP-MS } \\
\text { (erythrocyte) }\end{array}$ & 8 \\
\hline Suadicani,2012 & Denmark & $\begin{array}{l}\text { The } \\
\text { Copenhagen } \\
\text { Male Study }\end{array}$ & M & $\begin{array}{l}53- \\
74\end{array}$ & 16 & $\geq 102.65$ & $\leq 78.96$ & Total deaths $(1428 / 1905)$ & AAS(serum) & 7 \\
\hline Goyal,2013 & USA & $\begin{array}{l}\text { The Third } \\
\text { National } \\
\text { Health and } \\
\text { Nutrition } \\
\text { Examination } \\
\text { Survey }\end{array}$ & $M / F$ & $\begin{array}{l}20- \\
90\end{array}$ & 14.2 & $\geq 136.6$ & $\leq 109$ & $\begin{array}{l}\text { CVD mortality }(1891 / 14117), \text { Total } \\
\text { deaths }(4225 / 11783)\end{array}$ & AAS(serum) & 8 \\
\hline Alehagen,2016 & Sweden & $\begin{array}{l}\text { The National } \\
\text { Board of } \\
\text { Health and } \\
\text { Welfare in } \\
\text { Sweden }\end{array}$ & $M / F$ & $\begin{array}{l}70- \\
80\end{array}$ & 6.8 & $>76.1$ & $<57.2$ & $\begin{array}{l}\text { CVD mortality (85/449), Total deaths } \\
(122 / 327)\end{array}$ & $\begin{array}{l}\text { ICP-MS } \\
\text { \serum) }\end{array}$ & 6 \\
\hline
\end{tabular}

CVD cardiovascular disease, CHD coronary heart disease, MI myocardial infarction

Nine RCTs studies were published from 1989 to 2019, involved 37,057 participants. The follow-up periods ranged from 0.5 to 10 years. Three of RCTs used selenium alone, the others used selenium with other minerals. The selenium dose of studies included 4 studies of $200 \mu \mathrm{g} / \mathrm{d}, 3 \mathrm{studies}$ of $100 \mu \mathrm{g} / \mathrm{d}$, and $1 \mathrm{study}$ of $75 \mu \mathrm{g} / \mathrm{d}$. The detail characteristics of the RCTs were shown in the Table 2. 
Table 2

Characteristics of the randomized controlled trials

\begin{tabular}{|c|c|c|c|c|c|c|c|c|c|}
\hline Author, year & Country & Sex & $\begin{array}{l}\text { Age } \\
\text { (years) }\end{array}$ & $\begin{array}{l}\text { Follow- } \\
\text { up } \\
\text { (years) }\end{array}$ & $\begin{array}{l}\text { Dose } \\
(\mu g / d)\end{array}$ & $\begin{array}{l}\text { Selenium } \\
\text { combination }\end{array}$ & Outcomes & cases/controls & Quality \\
\hline Korpela,1989 & Finland & $M / F$ & 57 & 0.5 & 100 & NO & CHD mortality & Placebo:6/41 Treatment:1/40 & 2 \\
\hline Kuklinski,1994 & Germany & NR & 61.5 & 1 & 100 & Coenzyme & MI mortality & Placebo:6/29 Treatment:0/32 & 2 \\
\hline Brown,2001 & $\begin{array}{l}\text { Canada } \\
\text { and USA }\end{array}$ & $M / F$ & 53 & 3 & 100 & $\begin{array}{l}\text { Vitamin } E_{;} \\
\text {vitamin } \mathrm{C} ; \beta- \\
\text { carotene }\end{array}$ & $\begin{array}{l}\text { CVD mortality MI } \\
\text { mortality }\end{array}$ & Placebo:8/76 Treatment:6/84 & 5 \\
\hline You,2001 & China & $M / F$ & 47 & 3.3 & 75 & $\begin{array}{l}\text { garlic, garlic oil, } \\
\text { vitamin C, } \\
\text { vitamin E, } \beta- \\
\text { carotene }\end{array}$ & $\begin{array}{l}\text { CVD mortality } \\
\text { Total death }\end{array}$ & $\begin{array}{l}\text { Placebo:12/1705,43/1705 } \\
\text { Treatment:9/1706,38/1706 }\end{array}$ & 5 \\
\hline Hercberg,2004 & France & $M / F$ & 48 & 7.5 & 100 & $\begin{array}{l}\text { Vitamin } C, \\
\text { vitamin } E, \beta- \\
\text { carotene, and Zn }\end{array}$ & $\begin{array}{l}\text { CHD incidence } \\
\text { Total death }\end{array}$ & $\begin{array}{l}\text { Placebo:137/6377,98/6377 } \\
\text { Treatment:134/6364,76/6364 }\end{array}$ & 5 \\
\hline Stranges,2006 & USA & $M / F$ & 62 & 7.6 & 200 & NO & $\begin{array}{l}\text { CVD mortality, } \\
\text { CHD mortality, MI } \\
\text { mortality Total } \\
\text { death }\end{array}$ & $\begin{array}{l}\text { Placebo: } 96,59,43,111 / 500 \\
\text { Treatment:103,63,41,110/504 }\end{array}$ & 5 \\
\hline Klein,2011 & $\begin{array}{l}\text { USA, } \\
\text { Canada, } \\
\text { Puerto } \\
\text { Rico }\end{array}$ & M & 62.6 & 8.46 & 200 & NO & $\begin{array}{l}\text { CVD mortality } \\
\text { Total death }\end{array}$ & $\begin{array}{l}\text { Placebo:969/8696,939/8696 } \\
\text { Treatment:564/8752,551/8752 }\end{array}$ & 5 \\
\hline Lamas,2013 & $\begin{array}{l}\text { USA and } \\
\text { Canada }\end{array}$ & $M / F$ & 65 & 4.6 & 200 & multi-vitamins & $\begin{array}{l}\text { CVD mortality } \\
\text { Total death }\end{array}$ & $\begin{array}{l}\text { Placebo:56/855,93/855 } \\
\text { Treatment:45/853,87/853 }\end{array}$ & 5 \\
\hline Alehagen,2015 & Sweden & $M / F$ & 78 & 10 & 200 & Coenzyme & $\begin{array}{l}\text { CVD mortality } \\
\text { Total death }\end{array}$ & $\begin{array}{l}\text { Placebo:86/222,120/222 } \\
\text { Treatment:46/221,98/221 }\end{array}$ & 5 \\
\hline
\end{tabular}

2. Selenium and the risk of CVD and all-cause mortality in observational study

2.1 CVD

Eleven reports evaluated the association between serum selenium and the risk of CVD. We found a significant association of risk of CVD between the highest category and the lowest category (RR: $0.78 ; 95 \%$ Cl: $0.68-0.89 ;$ Fig. 2 ), with $22 \%$ lower risk of CVD in the highest category and evidence of between-study heterogeneity $(12=44.9 \%)$.

2.2 CHD

Eight reports investigated the risk of $\mathrm{CHD}$ between the highest and lowest category of serum selenium. The pooled result showed a significant inverse correlation (RR: $0.75 ; 95 \% \mathrm{Cl}: 0.58-0.95$; Fig. 2), with moderate heterogeneity (I2 = 34.1\%).

$2.3 \mathrm{Ml}$

Eight reports estimated the association between serum selenium and MI. The pooled results suggested that there was no significant association between the highest and the lowest category (RR: $0.78 ; 95 \% \mathrm{Cl}$ : 0.58-1.03; I2 = 35.8\%); Fig. 3).

\subsection{Stroke}

There were only three reports investigated the association between the serum selenium and the risk of stroke. We found there was no significant association between the highest category and the lowest category (RR: 1.18; $95 \% \mathrm{Cl}: 0.71-1.96 ; \mathrm{I}=36.1 \%$; Fig. 3 ).

\subsection{All-cause mortality}

When we compared the highest category of serum selenium with the lowest category, the pooled of RR of all-cause mortality was 0.77 (95\% Cl: $0.71-0.84$; Fig. 4); with substantial between-study heterogeneity $(I 2=61.4 \%)$.

3. Selenium and the risk of CVD and all-cause mortality in RCTs

\subsection{Total CVD}

There were only 12 reports from 9 RCTs studies. Because of the limited number of datasets, we considered all outcomes as total CVD. We found a significant association with a $22 \%$ lower risk of total CVD when compared the selenium supplement group to placebo group (RR: 0.78 ; $95 \%$ Cl: $0.62-0.98$ ), and with high heterogeneity $(\mathrm{I} 2=77.3 \%)$. The pooled RR was $0.76(95 \% \mathrm{Cl}: 0.49-1.16)$ for the 6 reports with a dose of $\leq 100 \mu \mathrm{g} / \mathrm{day}$ and $0.79(95 \% \mathrm{Cl}: 0.60-1.05)$ for the rest of the reports with a dose of $200 \mu \mathrm{g} /$ day selenium supplements (Fig. 5). 
About the all-cause mortality in RCTs studies, the association with selenium was a significant association between selenium supplement group and placebo group (RR: 0.81 ; $95 \%$ Cl: $0.65-1.00 ; 12=83.1 \%)$. The pooled RR was 0.81 (95\% Cl: $0.63-1.03)$ for the dose of $\leq 100 \mu \mathrm{g} / \mathrm{day}(2 \mathrm{studies})$ and 0.80 (95\% Cl: $0.60-$ 1.07) for the dose of $200 \mu \mathrm{g} /$ day (4 studies) selenium supplements (Fig. 6).

\section{Subgroup analyses and meta-regression}

To explore the potential source of heterogeneity, we performed subgroup analyses of sex, sample size, duration of follow-up, and selenium supplements. The analysis result was presented in Table 3 and Table 4. The association between selenium and the risk of CVD and all-cause mortality were similar with our main analyses. The meta-regression did not materially modify the pooled association. In observational studies, the duration of follow-up in CVD and sex in allcause mortality $(P=0.005,0.004$; respectively) had significant difference in the meta-regression. And in RCTs studies, the follow-up and supplements in allcause mortality also had significant difference $(P=0.012,0.001$; respectively). 
Table 3

Subgroup analysis of prospective observational studies

\begin{tabular}{|c|c|c|c|c|}
\hline & $\mathbf{N}$ & $\mathrm{RR}(95 \% \mathrm{Cl})$ & $P(\%)$ & $P$ value \\
\hline \multicolumn{5}{|l|}{ CVD } \\
\hline \multicolumn{5}{|l|}{ Sex } \\
\hline male & 2 & $0.86(0.77,0.98)$ & 59.6 & 0.299 \\
\hline male and female & 8 & $0.79(0.71,0.88)$ & 45.2 & \\
\hline \multicolumn{5}{|l|}{ Sample size } \\
\hline$\leq 500$ & 2 & $0.64(0.39,0.89)$ & 0 & 0.292 \\
\hline$>500$ & 8 & $0.83(0.76,0.90)$ & 52.8 & \\
\hline \multicolumn{5}{|l|}{ Follow-up (years) } \\
\hline$\leq 10$ & 5 & $0.55(0.41,0.74)$ & 0 & 0.005 \\
\hline$>10$ & 5 & $0.85(0.76,0.95)$ & 32.7 & \\
\hline \multicolumn{5}{|c|}{ Coronary heart disease } \\
\hline \multicolumn{5}{|l|}{ Sex } \\
\hline male & 3 & $0.74(0.56,0.99)$ & 0 & 0.722 \\
\hline male and female & 6 & $0.71(0.47,1.06)$ & 55.4 & \\
\hline \multicolumn{5}{|l|}{ Sample size } \\
\hline$\leq 500$ & 3 & $0.45(0.14,1.47)$ & 66.8 & 0.129 \\
\hline$>500$ & 6 & $0.81(0.67,0.98)$ & 0 & \\
\hline \multicolumn{5}{|l|}{ follow-up (years) } \\
\hline$\leq 10$ & 6 & $0.65(0.44,0.96)$ & 39.8 & 0.241 \\
\hline$>10$ & 3 & $0.85(0.64,1.13)$ & 18.5 & \\
\hline \multicolumn{5}{|c|}{ Myocardial infarction } \\
\hline \multicolumn{5}{|l|}{ Sex } \\
\hline male & 7 & $0.48(0.32,0.71)$ & - & 0.014 \\
\hline male and female & 1 & $0.87(0.67,1.12)$ & 0 & \\
\hline \multicolumn{5}{|l|}{ Sample size } \\
\hline$\leq 500$ & 4 & $0.98(0.66,1.46)$ & 0 & 0.081 \\
\hline$>500$ & 4 & $0.68(0.46,1.01)$ & 54.5 & \\
\hline \multicolumn{5}{|l|}{ Follow-up (years) } \\
\hline$\leq 10$ & 7 & $0.74(0.54,1.00)$ & 34.6 & 0.189 \\
\hline$>10$ & 1 & $1.00(0.60,1.68)$ & - & \\
\hline \multicolumn{5}{|l|}{ All-cause mortality } \\
\hline Sex & 3 & $0.87(0.81,0.94)$ & 0 & 0.004 \\
\hline female & 2 & $0.69(0.57,0.85)$ & 0 & \\
\hline male and female & 9 & $0.74(0.66,0.83)$ & 62.1 & \\
\hline \multicolumn{5}{|l|}{ Sample size } \\
\hline$\leq 500$ & 2 & $0.81(0.66,1.01)$ & 0 & 0.852 \\
\hline$>500$ & 12 & $0.76(0.70,0.84)$ & 66.7 & \\
\hline \multicolumn{5}{|l|}{ Follow-up (years) } \\
\hline$\leq 10$ & 7 & $0.67(0.56,0.80)$ & 33.6 & 0.05 \\
\hline$>10$ & 7 & $0.80(0.73,0.88)$ & 71.2 & \\
\hline
\end{tabular}


Table 4

Subgroup analysis of RCTs

\begin{tabular}{|c|c|c|c|c|}
\hline & $\mathbf{N}$ & $\mathrm{RR}(95 \% \mathrm{Cl})$ & $P(\%)$ & $P$ value \\
\hline \multicolumn{5}{|l|}{ Total CVD } \\
\hline \multicolumn{5}{|l|}{ Follow-up (years) } \\
\hline$\leq 5$ & 6 & $0.73(0.53,1.00)$ & 0 & 0.688 \\
\hline$>5$ & 6 & $0.82(0.62,1.09)$ & 88.5 & \\
\hline \multicolumn{5}{|l|}{ Supplements } \\
\hline Selenium alone & 5 & $0.83(0.56,1.23)$ & 88 & 0.089 \\
\hline Combined with others & 7 & $0.73(0.54,0.98)$ & 50.9 & \\
\hline \multicolumn{5}{|l|}{ All-cause mortality } \\
\hline \multicolumn{5}{|l|}{ Follow-up (years) } \\
\hline$\leq 5$ & 2 & $0.92(0.73,1.16)$ & 0 & 0.012 \\
\hline$>5$ & 4 & $0.77(0.59,1.00)$ & 82.9 & \\
\hline \multicolumn{5}{|l|}{ Supplements } \\
\hline Selenium alone & 2 & $0.75(0.45,1.25)$ & 93.9 & 0.001 \\
\hline Combined with others & 4 & $0.84(0.74,0.96)$ & 0 & \\
\hline
\end{tabular}

\section{Publication bias}

Egger's and Begg's tests suggested that there were no significant publication bias for the association of selenium and the risk of CVD and all-cause mortality. Since the limited number of datasets, the stroke group did not have publication bias test.

\section{Discussion}

Our meta-analysis was based on 25 prospective observational studies and 9 RCTs, with 225,829 participants and 22,272 cases in 14 different countries, provided the robust up-to-date evidence of the protective effects of selenium in CVD, CHD, and all-cause mortality. In observational studies, the selenium had a significant association with $22 \%, 25 \%$, and $23 \%$ lower risk in CVD, CHD, and all-cause mortality, respectively.

Our meta-analysis of RCTs results showed that the selenium supplements had a significant association with $22 \%$ and $19 \%$ lower risk of total CVD and allcause mortality. The between-study heterogeneity was significant high. The subgroup and meta-regression analysis results showed the possible sources of heterogeneity were dosage, duration and combinations of supplements. The results of RCTs were inconsistent with the previous meta-analyses(12, 13), which may have been due to the limited number of studies in the previous two meta-analysis.

The trace element of selenium is essential for the all living cells. The human selenoproteome has 25 seleoprotein, including glutathione peroxidase (GPX) family members (cellular or extracellular), phospholipid hydroperoxide, gastrointestinal GPX, and so on, which are encoded by 25 separate genes(46, 60). The seleoproteins are expressed in a variety of tissues, cells and exhibit numerous functions(61), for example, glutathione peroxidases (GPx) can protect the cells from lipoprotein and/or DNA damage by detoxifying intracellular hydrogen peroxide, thioredoxin reductases (TrxR) can balance the redox status of the cell by regenerating thioredoxin(62). Selenium can affect cardiovascular disease through anti-oxidative stress and anti-lipid peroxidation. The lack of serum selenium and the decrease of selenoprotein GPx activity lead to increased levels of oxidative stress and increased risk of myocardial infarction(63). Increased expression of GPx can reduce reperfusion injury after myocardial infarction(64). Selenium can also mediate cardiovascular disease through inflammation and vascular endothelial damage. Previous study showed that increased selenium intake not only reduced myocardial infarct size and post-ischemia tumor necrosis factor (TNF-a) expression, but also reduced myocardial reperfusion injury(65). Some studies have also shown that lack of selenium in cardiomyocytes results in decreased expression of potassium channels, reduced mitochondrial activity and decreased mitochondrial function, which in turn promotes cardiomyocyte apoptosis(66,67).

To our knowledge, this paper is the first meta-analysis to estimate the association between selenium and specific cardiovascular risks, including CVD, CHD, MI and stroke. Meanwhile, this paper is also the first meta-analysis to explore the selenium supplement and the risk of all-cause mortality.

The strength of our study lay in four aspects. First, we conducted a comprehensive search method and the all the inclusion studies were obtained through rigorous screening, which made us unlikely missing any major published reported. Meanwhile according to the Newcastle-Ottawa and Jadad scale, the average quality of all included studies was high, which significantly increased the statistical power of the analysis. Second, we limited the included studies to prospective studies and RCTs, which greatly limited the recall bias. Third, we separated evaluated CVD, CHD, MI and stroke, which could increase the possibility of finding the different effect of selenium and the risk of CVD. Finally, there were no publication bias in our meta-analysis. 
On the other hand, some limitations of meta-analysis must be considered. First, the quality of the included studies in our meta-analysis was varied. Although some studies were adjusted the potential confounding factors, (age, sex, smoking and so on), serum antioxidants or vitamins levels might be different. Thus, it was difficult to evaluate the other nutrients contribution our observed association. Second, the included observational studies used three methods to assess the serum selenium. The categories of serum selenium were not identical, which led to a big difference of the highest categories of serum selenium in the referenced studies, and then likely affected the true association between selenium and CVD. Finally, the results of RCTs should be conservative as the between-study in RCTs studies were high and could not be omitted.

\section{Conclusion}

In conclusion, our meta-analysis of 25 prospective observational studies suggested a significant association between serum selenium and the risk of CVD, $\mathrm{CHD}$, and all-cause mortality, in contrast, we found no correction between serum selenium and the risk of Ml, and stroke. Our meta-analysis of 9 RCTs found beneficial effect of selenium supplements on total CVD and all-cause mortality. Our findings support the hypothesis that increasing concentration of serum selenium and/or selenium supplements has a potential effect on against cardiovascular disease and all-cause mortality.

\section{Abbreviations}

CVD: cardiovascular disease; CHD: coronary heart disease; MI: myocardial infarction; Gpx: glutathione peroxidase

\section{Declarations}

\section{Ethics approval and consent to participate Conflict of Interests}

Not applicable

\section{Availability of data and materials}

All data are fully available without restriction.

\section{Consent for publication}

Not applicable

\section{Competing interests}

The authors declare no competing interests.

\section{Funding Statement}

This work was supported by the National Nature Science Foundation of China [grants number 81872626]

\section{Author Contributions}

Hualei Sun conceived the study design, supervision of data collection, data analysis and writing the manuscript. Shao Rong Long and Wenjie Li undertook data collection and data analysis. Gaiyun Chen, Yajuan Wang, Like Zhang and Rui Liang undertook data collection

\section{Acknowledgement}

None

\section{References}

1. Rayman MP. The importance of selenium to human health. Lancet. 2000;356(9225):233 - 41.

2. Navas-Acien A, Bleys J, Guallar E. Selenium intake and cardiovascular risk: what is new? Curr Opin Lipidol. 2008;19(1):43 - 9.

3. Navarro-Alarcon M, Cabrera-Vique C. Selenium in food and the human body: a review. The Science of the total environment. 2008;400(1-3):115 - 41.

4. Ellis DR, Sors TG, Brunk DG, Albrecht C, Orser C, Lahner B, et al. Production of Se-methylselenocysteine in transgenic plants expressing selenocysteine methyltransferase. Bmc Plant Biol. 2004;4:1.

5. Levander O. The need for measures of selenium status. J Am Coll Toxicol. 1986;5(1):37-44.

6. Levander OA. A global view of human selenium nutrition. Annu Rev Nutr. 1987;7:227 - 50

7. Ovaskainen ML, Virtamo J, Alfthan G, Haukka J, Pietinen P, Taylor PR, et al. Toenail selenium as an indicator of selenium intake among middle-aged men in an area with low soil selenium. Am J Clin Nutr. 1993;57(5):662-5.

8. Rayman MP. Selenium and human health. Lancet. 2012;379(9822):1256-68. 
9. Rose AH, Hoffmann PR. Selenoproteins and cardiovascular stress. Thrombosis and haemostasis. 2015;113(3):494-504.

10. Reffelmann T, Ittermann T, Dorr M, Volzke H, Reinthaler M, Petersmann A, et al. Low serum magnesium concentrations predict cardiovascular and all-cause mortality. Atherosclerosis. 2011;219(1):280-4.

11. Navarro-Alarcon M, Lopez-Martinez MC. Essentiality of selenium in the human body: relationship with different diseases. The Science of the total environment. 2000;249(1-3):347- 71 .

12. Flores-Mateo G, Navas-Acien A, Pastor-Barriuso R, Guallar E. Selenium and coronary heart disease: a meta-analysis. Am J Clin Nutr. $2006 ; 84(4): 762$ - 73.

13. Zhang X, Liu C, Guo J, Song Y. Selenium status and cardiovascular diseases: meta-analysis of prospective observational studies and randomized controlled trials. European journal of clinical nutrition. 2016;70(2):162-9.

14. Ju W, Li X, Li Z, Wu GR, Fu XF, Yang XM, et al. The effect of selenium supplementation on coronary heart disease: A systematic review and meta-analysis of randomized controlled trials. J Trace Elem Med Biol. 2017;44:8-16.

15. Stroup DF, Berlin JA, Morton SC, Olkin I, Williamson GD, Rennie D, et al. Meta-analysis of observational studies in epidemiology: a proposal for reporting. Meta-analysis Of Observational Studies in Epidemiology (MOOSE) group. Jama. 2000;283(15):2008-12.

16. Liberati A, Altman DG, Tetzlaff J, Mulrow C, Gotzsche PC, loannidis JP, et al. The PRISMA statement for reporting systematic reviews and meta-analyses of studies that evaluate healthcare interventions: explanation and elaboration. BMJ (Clinical research ed). 2009;339:b2700.

17. Moher D, Liberati A, Tetzlaff J, Altman DG. Preferred reporting items for systematic reviews and meta-analyses: the PRISMA statement. BMJ (Clinical research ed). 2009;339:b2535.

18. Stang A. Critical evaluation of the Newcastle-Ottawa scale for the assessment of the quality of nonrandomized studies in meta-analyses. Eur J Epidemiol. 2010;25(9):603-5.

19. Jadad AR, Moore RA, Carroll D, Jenkinson C, Reynolds DJ, Gavaghan DJ, et al. Assessing the quality of reports of randomized clinical trials: is blinding necessary? Controlled clinical trials. 1996;17(1):1-12.

20. Zhang J, Yu KF. What's the relative risk? A method of correcting the odds ratio in cohort studies of common outcomes. Jama. 1998;280(19):1690-1.

21. McNutt L-A, Wu C, Xue X, Hafner JP. Estimating the relative risk in cohort studies and clinical trials of common outcomes. Am J Epidemiol. 2003;157(10):940-3.

22. Ray AL, Semba RD, Walston J, Ferrucci L, Cappola AR, Ricks MO, et al. Low serum selenium and total carotenoids predict mortality among older women living in the community: the women's health and aging studies. J Nutr. 2006;136(1):172-6.

23. Kilander L, Berglund L, Boberg M, Vessby B, Lithell H. Education, lifestyle factors and mortality from cardiovascular disease and cancer. A 25-year followup of Swedish 50-year-old men. Int J Epidemiol. 2001;30(5):1119-26.

24. Bates CJ, Hamer M, Mishra GD. Redox-modulatory vitamins and minerals that prospectively predict mortality in older British people: The National Diet and Nutrition Survey of people aged 65 years and over. Brit J Nutr. 2011;105(1):123 - 32.

25. Hamling J, Lee P, Weitkunat R, Ambuhl M. Facilitating meta-analyses by deriving relative effect and precision estimates for alternative comparisons from a set of estimates presented by exposure level or disease category. Statistics in medicine. 2008;27(7):954 - 70.

26. Higgins JP, Thompson SG, Deeks JJ, Altman DG. Measuring inconsistency in meta-analyses. BMJ (Clinical research ed). 2003;327(7414):557 - 60.

27. Begg CB, Mazumdar M. Operating characteristics of a rank correlation test for publication bias. Biometrics. 1994;50(4):1088 - 101.

28. Egger M, Davey Smith G, Schneider M, Minder C. Bias in meta-analysis detected by a simple, graphical test. BMJ (Clinical research ed). 1997;315(7109):629-34.

29. Salonen JT, Alfthan G, Huttunen JK, Pikkarainen J, Puska P. Association between cardiovascular death and myocardial infarction and serum selenium in a matched-pair longitudinal study. Lancet. 1982;2(8291):175-9.

30. Miettinen TA, Alfthan G, Huttunen JK, Pikkarainen J, Naukkarinen V, Mattila S, et al. Serum selenium concentration related to myocardial infarction and fatty acid content of serum lipids. British medical journal (Clinical research ed). 1983;287(6391):517-9.

31. Salonen JT, Salonen R, Penttila I, Herranen J, Jauhiainen M, Kantola M, et al. Serum fatty acids, apolipoproteins, selenium and vitamin antioxidants and the risk of death from coronary artery disease. Am J Cardiol. 1985;56(4):226 - 31.

32. Virtamo J, Valkeila E, Alfthan G, Punsar S, Huttunen JK, Karvonen MJ. Serum selenium and the risk of coronary heart disease and stroke. Am J Epidemiol. $1985 ; 122(2): 276-82$. 
33. Ringstad J, Thelle D. Risk of myocardial infarction in relation to serum concentrations of selenium. Acta Pharmacol Toxicol (Copenh). 1986;59 Suppl 7:336-9.

34. Kok FJ, de Bruijn AM, Vermeeren R, Hofman A, van Laar A, de Bruin M, et al. Serum selenium, vitamin antioxidants, and cardiovascular mortality: a 9-year follow-up study in the Netherlands. Am J Clin Nutr. 1987;45(2):462-8.

35. Ringstad J, Jacobsen BK, Thomassen Y, Thelle DS. The Tromso Heart Study: serum selenium and risk of myocardial infarction a nested case-control study. J Epidemiol Community Health. 1987;41(4):329 - 32.

36. Suadicani P, Hein HO, Gyntelberg F. Serum selenium concentration and risk of ischaemic heart disease in a prospective cohort study of 3000 males. Atherosclerosis. 1992;96(1):33-42.

37. Salvini S, Hennekens CH, Morris JS, Willett WC, Stampfer MJ. Plasma levels of the antioxidant selenium and risk of myocardial infarction among U.S. physicians. Am J Cardiol. 1995;76(17):1218-21.

38. Marniemi J, Jarvisalo J, Toikka T, Raiha I, Ahotupa M, Sourander L. Blood vitamins, mineral elements and inflammation markers as risk factors of vascular and non-vascular disease mortality in an elderly population. Int J Epidemiol. 1998;27(5):799-807.

39. Yoshizawa K, Ascherio A, Morris JS, Stampfer MJ, Giovannucci E, Baskett CK, et al. Prospective study of selenium levels in toenails and risk of coronary heart disease in men. Am J Epidemiol. 2003;158(9):852 - 60.

40. Wei WQ, Abnet CC, Qiao YL, Dawsey SM, Dong ZW, Sun XD, et al. Prospective study of serum selenium concentrations and esophageal and gastric cardia cancer, heart disease, stroke, and total death. Am J Clin Nutr. 2004;79(1):80 - 5.

41. Akbaraly NT, Arnaud J, Hininger-Favier I, Gourlet V, Roussel AM, Berr C. Selenium and mortality in the elderly: results from the EVA study. Clin Chem. 2005;51(11):2117-23.

42. Bleys J, Navas-Acien A, Guallar E. Serum selenium levels and all-cause, cancer, and cardiovascular mortality among US adults. Arch Intern Med. 2008;168(4):404- 10 .

43. Eaton CB, Abdul Baki AR, Waring ME, Roberts MB, Lu B. The association of low selenium and renal insufficiency with coronary heart disease and all-cause mortality: NHANES III follow-up study. Atherosclerosis. 2010;212(2):689 - 94.

44. Wennberg M, Bergdahl IA, Hallmans G, Norberg M, Lundh T, Skerfving S, et al. Fish consumption and myocardial infarction: A second prospective biomarker study from northern Sweden. Am J Clin Nutr. 2011;93(1):27-36.

45. Goyal A, Terry MB, Siegel AB. Serum antioxidant nutrients, vitamin A, and mortality in U.S. Adults. Cancer epidemiology, biomarkers \& prevention : a publication of the American Association for Cancer Research, cosponsored by the American Society of Preventive Oncology. 2013;22(12):2202-11.

46. Alehagen U, Johansson P, Bjornstedt M, Rosen A, Post C, Aaseth J. Relatively high mortality risk in elderly Swedish subjects with low selenium status. Eur J Clin Nutr. 2016;70(1):91-6.

47. Walston J, Xue Q, Semba RD, Ferrucci L, Cappola AR, Ricks M, et al. Serum antioxidants, inflammation, and total mortality in older women. Am J Epidemiol. 2006;163(1):18-26.

48. Gonzalez S, Huerta JM, Fernandez S, Patterson AM, Lasheras C. Homocysteine increases the risk of mortality in elderly individuals. The British journal of nutrition. 2007;97(6):1138-43.

49. Lauretani F, Semba RD, Bandinelli S, Ray AL, Ruggiero C, Cherubini A, et al. Low plasma selenium concentrations and mortality among older communitydwelling adults: the InCHIANTI Study. Aging Clin Exp Res. 2008;20(2):153-8.

50. Suadicani P, Hein HO, Gyntelberg F. Serum selenium level and risk of lung cancer mortality: a 16-year follow-up of the Copenhagen Male Study. The European respiratory journal. 2012;39(6):1443-8.

51. Korpela H, Kumpulainen J, Jussila E, Kemila S, Kaariainen M, Kaariainen T, et al. Effect of selenium supplementation after acute myocardial infarction. Res Commun Chem Pathol Pharmacol. 1989;65(2):249 - 52.

52. Kuklinski B, Weissenbacher E, Fahnrich A. Coenzyme Q10 and antioxidants in acute myocardial infarction. Mol Aspects Med. 1994;15 Suppl:s143-7.

53. Brown BG, Zhao XQ, Chait A, Fisher LD, Cheung MC, Morse JS, et al. Simvastatin and niacin, antioxidant vitamins, or the combination for the prevention of coronary disease. The New England journal of medicine. 2001;345(22):1583-92.

54. You WC, Chang YS, Heinrich J, Ma JL, Liu WD, Zhang L, et al. An intervention trial to inhibit the progression of precancerous gastric lesions: compliance, serum micronutrients and S-allyl cysteine levels, and toxicity. Eur J Cancer Prev. 2001;10(3):257 - 63.

55. Hercberg S, Galan P, Preziosi P, Bertrais S, Mennen L, Malvy D, et al. The SU.VI.MAX study - A randomized, placebo-controlled trial of the health effects of antioxidant vitamins and minerals. Arch Intern Med. 2004;164(21):2335-42.

Page $12 / 16$ 
56. Stranges S, Marshall JR, Trevisan M, Natarajan R, Donahue RP, Combs GF, et al. Effects of selenium supplementation on cardiovascular disease incidence and mortality: secondary analyses in a randomized clinical trial. Am J Epidemiol. 2006;163(8):694-9.

57. Klein EA, Thompson IM, Jr., Tangen CM, Crowley JJ, Lucia MS, Goodman PJ, et al. Vitamin E and the Risk of Prostate Cancer The Selenium and Vitamin E Cancer Prevention Trial (SELECT). Jama-J Am Med Assoc. 2011;306(14):1549-56.

58. Lamas GA, Boineau R, Goertz C, Mark DB, Rosenberg Y, Stylianou M, et al. Oral high-dose multivitamins and minerals after myocardial infarction: A randomized trial. Ann Intern Med. 2013;159(12):797-804.

59. Alehagen U, Aaseth J, Johansson P. Reduced Cardiovascular Mortality 10 Years after Supplementation with Selenium and Coenzyme Q10 for Four Years: Follow-Up Results of a Prospective Randomized Double-Blind Placebo-Controlled Trial in Elderly Citizens. Plos One. 2015;10(12):e0141641.

60. Kryukov GV, Castellano S, Novoselov SV, Lobanov AV, Zehtab O, Guigo R, et al. Characterization of mammalian selenoproteomes. Science (New York, NY). 2003;300(5624):1439-43.

61. Reeves MA, Hoffmann PR. The human selenoproteome: recent insights into functions and regulation. Cell Mol Life Sci. 2009;66(15):2457-78.

62. Benstoem C, Goetzenich A, Kraemer S, Borosch S, Manzanares W, Hardy G, et al. Selenium and its supplementation in cardiovascular disease-what do we know? Nutrients. 2015;7(5):3094 - 118.

63. Swart R, Schutte AE, van Rooyen JM, Mels CMC. Serum selenium levels, the selenoprotein glutathione peroxidase and vascular protection: The SABPA study. Food Res Int. 2018;104:69-76.

64. Eckers JC, Kalen AL, Xiao W, Sarsour EH, Goswami PC. Selenoprotein P inhibits radiation-induced late reactive oxygen species accumulation and normal cell injury. International journal of radiation oncology, biology, physics. 2013;87(3):619 - 25.

65. Tanguy S, Rakotovao A, Jouan MG, Ghezzi C, de Leiris J, Boucher F. Dietary selenium intake influences Cx43 dephosphorylation, TNF-alpha expression and cardiac remodeling after reperfused infarction. Molecular nutrition \& food research. 2011;55(4):522-9.

66. Bao G, Wu H, Yu D, Liu D, Wang H. Potassium channels on cardiomyocytes of selenium iodine deficiency rats and iodine deficiency rats. Chinese medical sciences journal = Chung-kuo i hsueh k'o hsueh tsa chih. 1997;12(1):57 - 9.

67. Zhang C, Deng Y, Lei Y, Zhao J, Wei W, Li Y. Effects of selenium on myocardial apoptosis by modifying the activity of mitochondrial STAT3 and regulating potassium channel expression. Exp Ther Med. 2017;14(3):2201-5.

\section{Figures}

Article identified through database searching $(\mathrm{n}=3859)$

Article from Pubmed $=614$

Article from Embase $=1572$

Article from Web of Science $=1673$

Article excluded:

Duplicates article $(\mathrm{n}=1238)$

Obvious irrelevance $(\mathrm{n}=2549)$

Potentially relevant article for more detailed assessment $(\mathrm{n}=65)$

Article excluded:

Case-control $(\mathrm{n}=4)$

Cross-selection $(\mathrm{n}=6)$

Other diseases $(\mathrm{n}=9)$

Duplicated data $(\mathrm{n}=12)$

Articles included in this meta-analysis( $\mathrm{n}=36$ )

Prospective studies $(\mathrm{n}=25)$

RCT studies $(\mathrm{n}=9)$

Figure 1

Page 13/16 
Flow-chart of study identified with inclusion and exclusion criteria

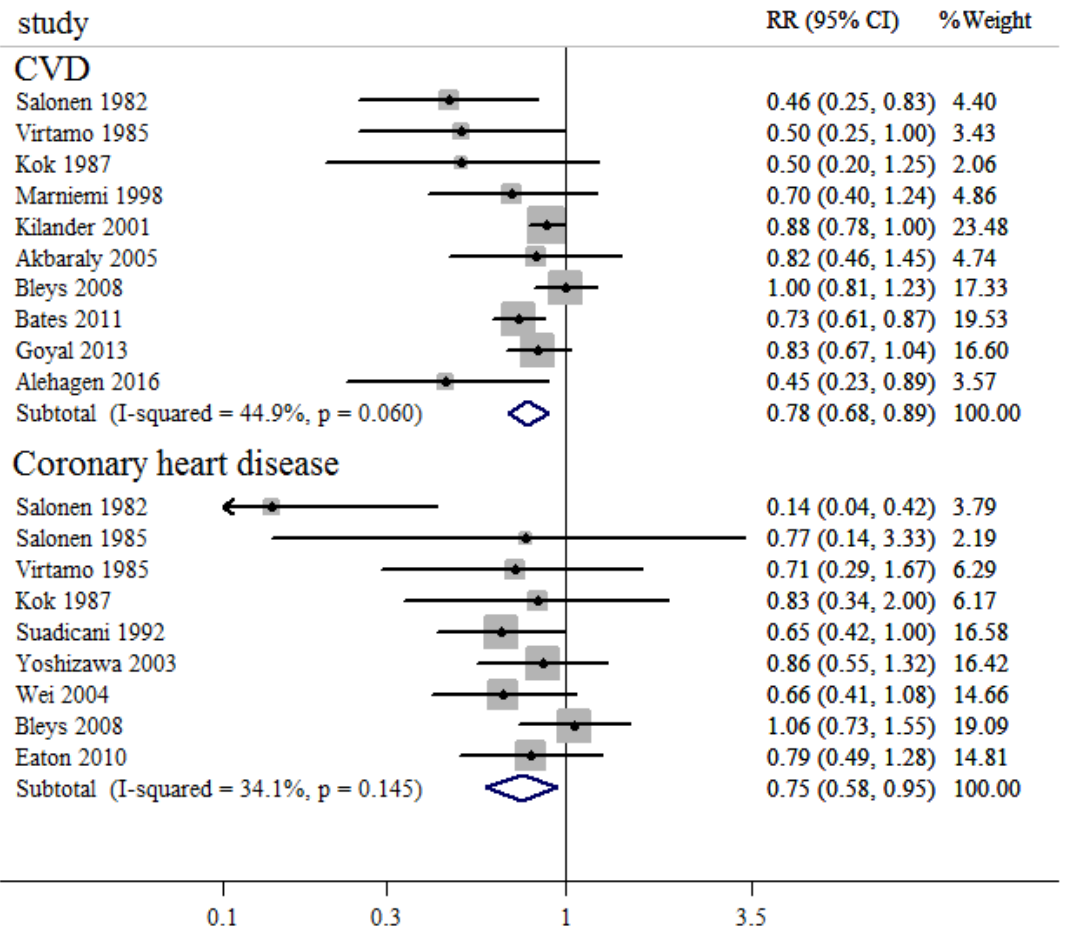

\section{Figure 2}

Forest plots of cardiovascular disease, coronary heart disease for the highest versus lowest categories of serum selenium in observational studies.

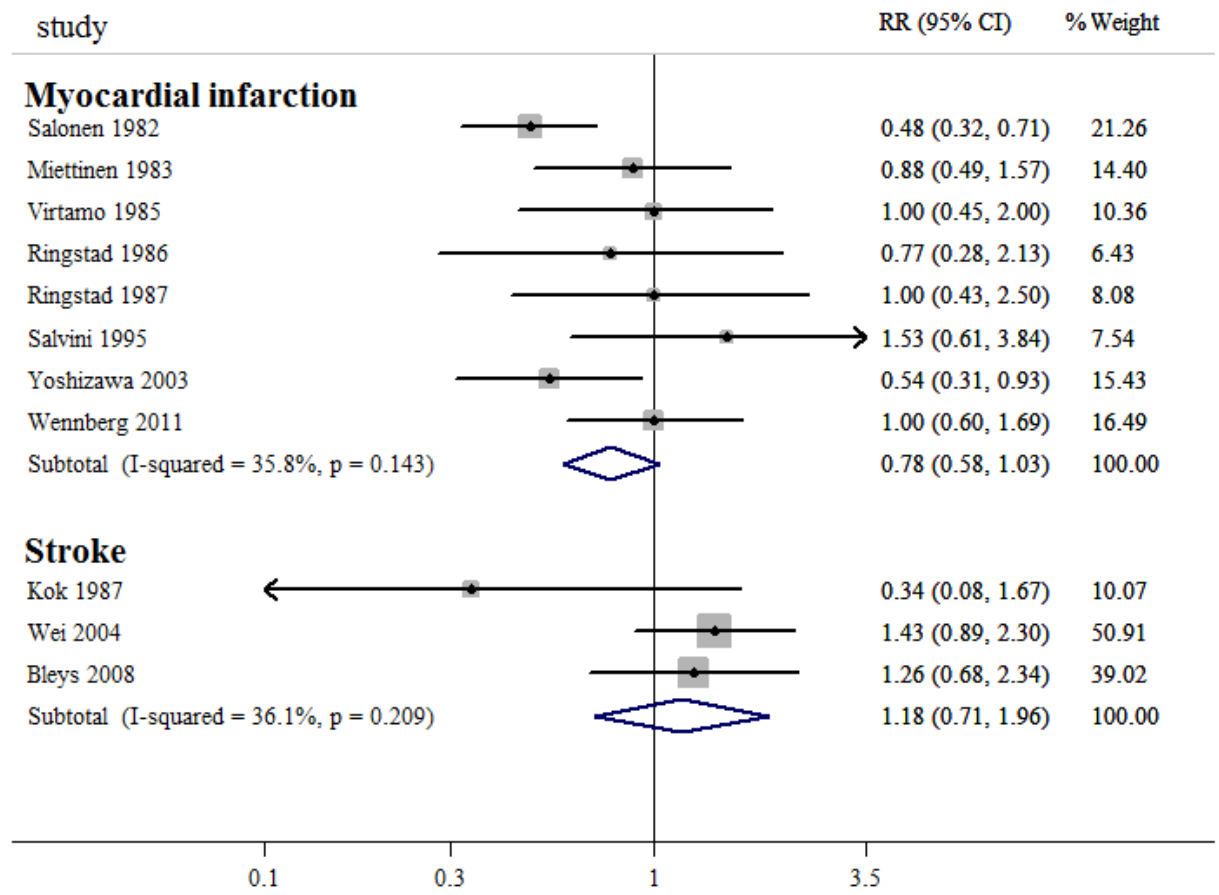

\section{Figure 3}

Forest plots myocardial infraction and stroke (B) for the highest versus lowest categories of serum selenium in observational studies. 




\section{Figure 4}

Forest plots of all-cause mortality for the highest versus lowest categories of serum selenium in observational studies.

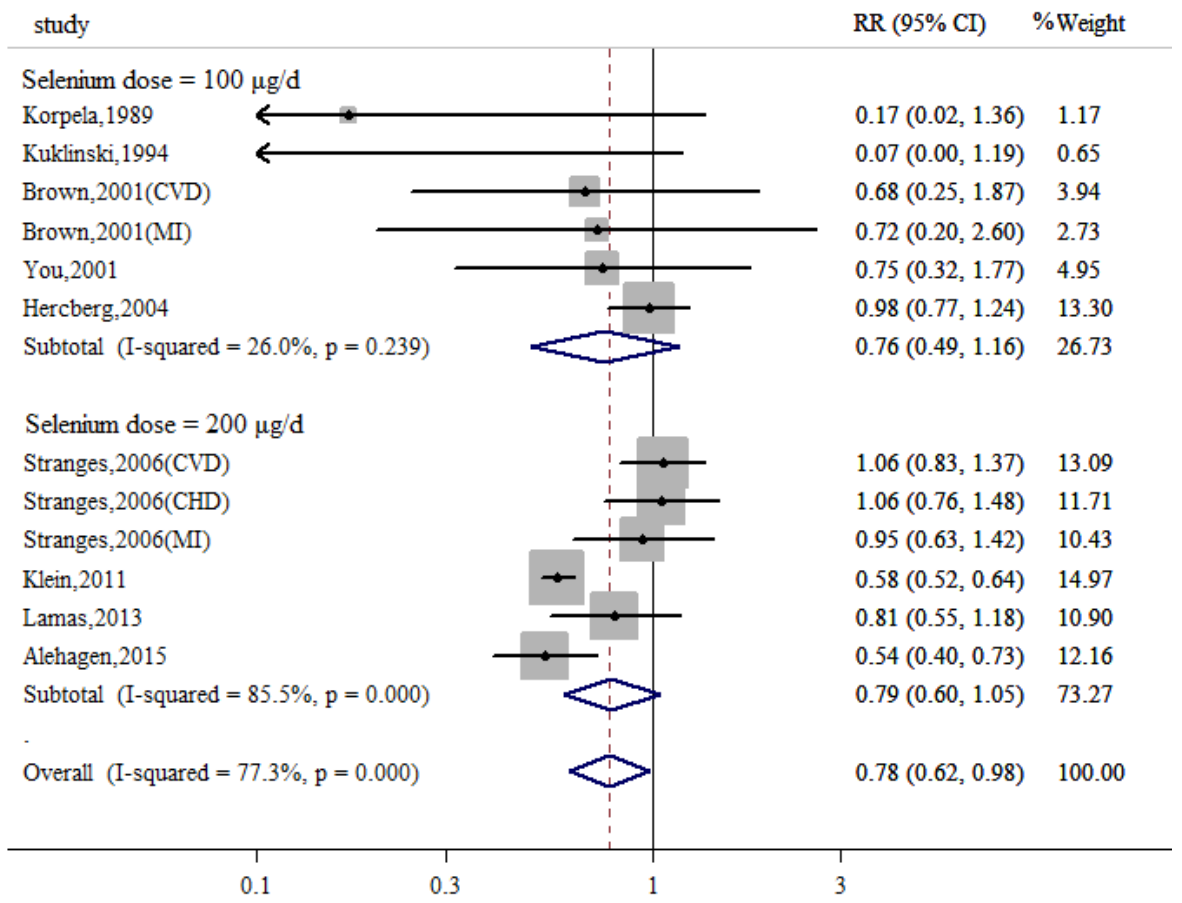

Figure 5

Forest plots of selenium supplement and the risk of total CVD in RCTs. 


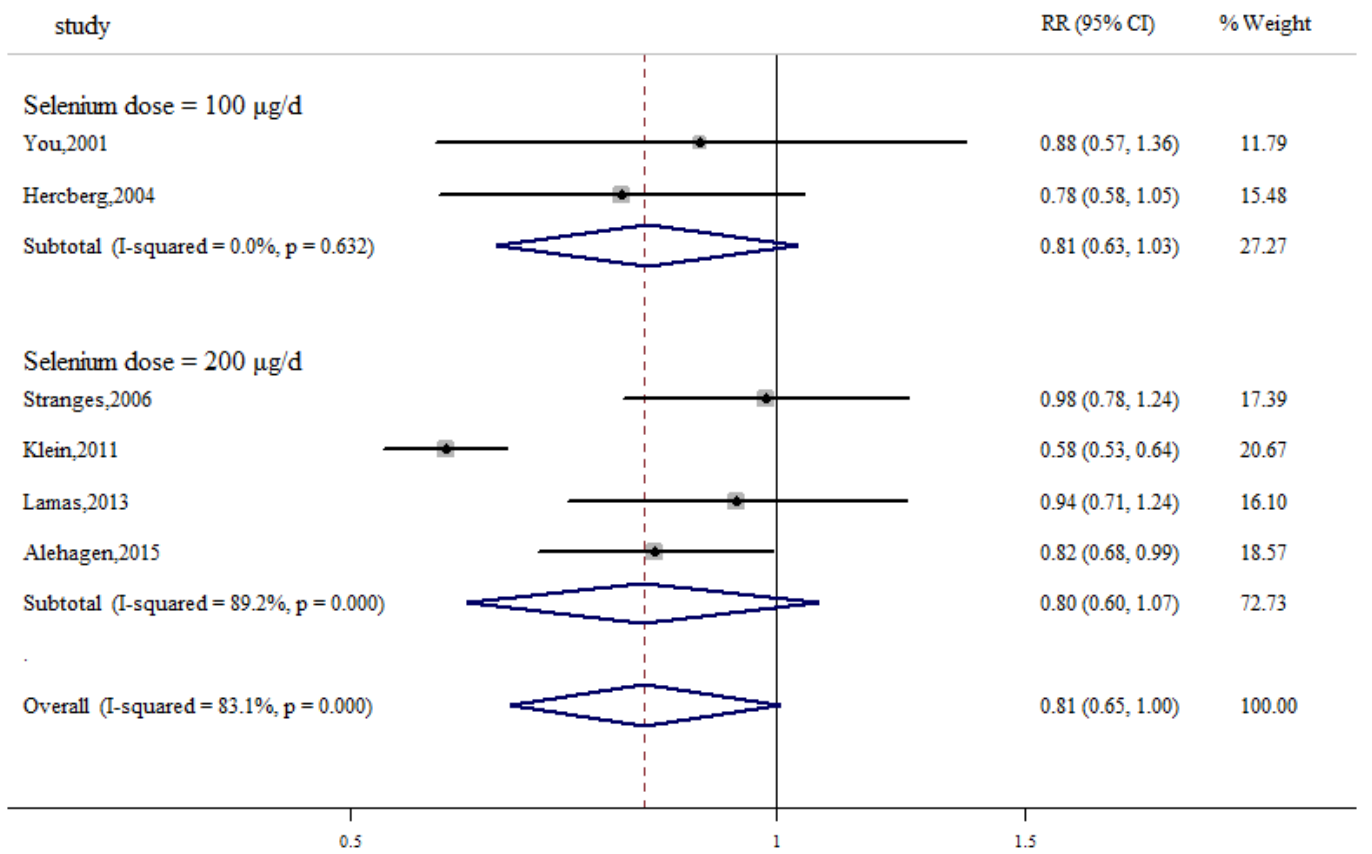

\section{Figure 6}

Forest plots of selenium supplement and the risk of all-cause mortality in RCTs. Selenium supplemental dose of You, $2001 \mathrm{was} 75 \mathrm{\mu g} / \mathrm{day}$.

\section{Supplementary Files}

This is a list of supplementary files associated with this preprint. Click to download.

- supplementarymaterial.docx 